\title{
THE EUROPEAN OMBUDSMAN IN THE FRAMEWORK OF THE EUROPEAN UNION*
}

\author{
LA FIGURA DEL DEFENSOR DEL PUEBLO EN EL MARCO DE LA \\ UNIÓN EUROPEA
}

Ana María Moure Pino**

ABSTRACT: In the framework of the Association Agreement between Chile and the European Union (UE) in 2002, which constitutes the juridical framework establishing a political and economic association between both parties that covers a wide range of areas, also includes the social development.

In this context we will study in detail the European Ombudsman, which is on the one hand, formally a parliamentary body at a supranational level, designed to strengthen the supervision and control of European Institutions and Administrations; besides, he has developed a specific new concept of maladministration and his faculties extended to the protection of fundamental rights.

The powers of the Ombudsman, give him the opportunity to combine the instruments of parliamentary scrutiny and judicial control in an original way. Another important aspect we would like to underline is that under certain circumstances the Chileans citizens could address this institution and at a state level it may be possible to maximize the effort of transferring the experience of this institution to Chile to enhance non-jurisdictional mechanisms to improve the accountability on the activities of the institutions of the State.

Key words: European Ombudsman, non-jurisdicctional control, Administration.

RESUMEN: En el marco del Acuerdo de Asociación celebrado entre Chile y la Unión Europea (UE) en el 2002, el cual constituye el marco jurídico principal de regulación de las relaciones políticas y comerciales entre ambas partes, se ha considerado también la cooperación hacia el desarrollo social.

En este contexto haremos un estudio detallado de la figura del Defensor del Pueblo Europeo, que se ha instaurado a nivel supranacional con facultades de supervisión y control de las instituciones comunitarias y sus administraciones; además, ha desarrollado a través de sus informes un concepto específico sobre la mala administración y sus facultades se han extendido también a la protección de los derechos fundamentales.

Sus potestades le permiten combinar instrumentos como el escrutinio parlamentario y el control jurisdiccional en una forma original. Otro aspecto importante es enfatizar que bajo ciertas circunstancias también los ciudadanos chilenos pueden acceder a esta institución, y a nivel estatal se podrían maximizar los esfuerzos en crear una institución análoga en Chile, con el objeto de dotar de recursos alternativos como método de control de las instituciones del Estado.

Palabras clave: Defensor del Pueblo Europeo, Control no jurisdiccional, Administración.

* This paper is the winner of the 2011. RCHD award, in the area of international law.

** Lawyer, Master in European Law, Leiden University, Doctor in European Law, University of Alcalá and Dresden Univeristy of Technology. Correo electrónico: amoure@derecho.uchile.cl 


\section{INTRODUCTION}

It is often said that the historical roots of the ombudsman principle and its modern development in European states led naturally to the idea of an Ombudsman for the European Union (hereinafter EU).

The European Parliament first adopted a resolution calling for the appointment of an Ombudsman in 1979. ${ }^{1}$ In the 1980s, the issue was again raised by the Adonnino Committee. ${ }^{2}$ In the negotiations that led to the Maastricht Treaty on European Union, proposals to establish the office of European Ombudsman were directly linked to the introduction to those of European citizenship. ${ }^{3}$

This has to be seen in the wider context of the European Union's Institutions and their commitment to protect citizen's rights, because the European Ombudsman was created by the Treaty of Maastricht in 1992, with the aim to enhance relations between citizens of the Union and the EU institutions and bodies.

The European Ombudsman (EO) has been in workplace for almost 20 years, this article examines some of its main characteristics. The office was modelled on different Ombudsmen of some of the Member States of the EU, with the combined effect of the enlargement of the EU, new offices have been established. Actually, there is a national Ombudsman in all Member States (27) and in candidate countries (Croatia, Iceland, Former Yugoslav Republic of Macedonia and Turkey $)^{4}$ have either established an Ombudsman, or announced their intention to do so.

\footnotetext{
${ }^{1}$ Resolution on the appointment of a Community Ombudsman by the European Parliament, 11 May 1979 [Official Journal 1979 C 140, p. 153], that expressed that the experience in many countries has shown that an independent extra-judicial institution such as the Ombudsman can provide a flexible and effective system for controlling the executive, ensuring that the law is justly applied, and protecting the citizen.

${ }^{2}$ The "Adonnino Report" - Report to the European Council by the ad hoc committee "On a People's Europe", A 10.04 COM 85, SN/2536/3/85. The Committee promoted, on the one hand, a uniform electoral procedure as regards the elections for the European Parliament and, on the other, ensuring greater transparency in administration in the Community by strengthening the citizen's right of petition, and by establishing an Ombudsman. The Adonnino Committee (named after its chairman, the Italian Pietro Adonnino) submitted two complementary reports which dealt with various issues such as with "easing of rules and practices which cause irritation to Community citizens and undermine the credibility of the Community" (Adonnino Report 1985/I: pt. A), with what has been termed "community citizen's rights" including for example: freedom of movement in working life, right of establishment and of residence and aspects of culture and communication as well as information about the EU and its specific policies, etc.

${ }^{3}$ The European Ombusman, Annual Report, 1995, p. 23.

Available at: http://www.ombudsman.europa.eu/activities/annualreports.faces

${ }^{4}$ It is significant that there has been substantial legislative and institutional convergence in Turkey towards European standards, in particular after the 2002 elections. The political reforms are mainly contained in two major constitutional reforms in 2001 and 2004 and eight legislative packages adopted by Parliament between February 2002 and July 2004. Civil-military relations are evolving towards European standards. Important changes have been made to the judicial system, including the abolition of the State Security Courts. Public administration reform is underway. As regards human rights, Turkey recognises the primacy of international and European law. It has aligned itself to a large extent with international conventions and rulings, such as the complete abolition of the death penalty and the release of people sentenced for expressing nonviolent opinion. Despite this, implementation needs to be further consolidated and broadened. This applies specifically to the zero tolerance policy in the fight against torture and ill-treatment, and the strengthening and implementation of provisions relating to freedom of expression, freedom of religion, women's rights,
} 
The EO has referred especially to the same institution established in the Nordic systems, France and Great Britain, seeing that some of the examples had inspired his mandate and powers. 5

Looking at the experience of these and other national Ombudsmen, this article intends to describe and analyse the role of the European Ombudsman acting as a nonjudicial and external control of the EU institutions in relation to poor administrative practices.

His functions are mainly related to identify when maladministration occurs and it is open to any citizen that lives within the territory of the EU.

At this respect he not only resolves problems for the citizens of the European Union but sometimes also obtains redress as far as individuals are concerned, with the aim to put them back in the position they would have been if the maladministration did not happen.

The question also arises as how is he able to go wider than simply looking for 'maladministration' and get changes made for the better protection of fundamental rights within the EU institutions.

Even though he cannot give a definitive view on interpretation of EU law -a matter for the Court of Justice (CJ) - he may be able to ask a body to hold action pending consideration of a complaint.

This chapter will first lay out the origin and some of the general characteristics of the European Ombudsman, his legal framework and functions in order to assess their mutual influence.

Second, it will study the scope of the Code of Good Administrative Behaviour, the EU Treaties and the Charter of Fundamental Rights, which have opened new possibilities to develop ombudsman's policy at EU level, whereas he can operate both as a controller and as a codifier.

From all this, it follows that the European Ombudsman is guided by the primacy of Community law and the fact that fundamental rights are an integral part of EU law, combined with the important implications these facts have as well, for each of the Ombudsmen in the Member States, at national, regional or local level.

Primacy requires all public authorities in the Member States to apply Community lawfully and correctly. Since Ombudsmen supervise public authorities, they have a key role to play in ensuring the fulfilment of this obligation. Less obvious perhaps, is that, since Ombudsmen themselves are public authorities, they must, within their field of competence, act to protect rights that derive from EU law.

trade union rights and minority rights. See: Recommendation of the European Commission on Turkey's progress towards accession (Brussels, 06.10 2004); Communication from the Commission to the Council and the European Parliament, 06.10.2004; COM (2004) 656 final;

Available at: http://www.ena.lu/recommendation_commission_turkeys_progress_accession_ october_2004-020005677.html

5 See: Speech of the European Ombudsman, Mr Jacoв SöDerman, given before the Court of Justice, 27 September 1995 "I am confident that the powers and the mandate of the European Ombudsman - partly modelled on the French "Médiateur de la République, the British 'Parliamentary Commissioner for Administration' and the Nordic systems offer the potential to carry out these tasks successfully" 
Equally, the role of Ombudsmen in EU Member States it is especially important because the implementation of EU law and policies is largely the responsibility of administrations in every Member State at a national level.

In practice, therefore, respect for fundamental rights depends largely on the quality of their everyday work and on the extent to which supervisory bodies, including Ombudsmen succeed in promoting high quality administration and providing effective remedies when needed. ${ }^{6}$

We must conclude that since the Treaty of Amsterdam the main goals of the EU the establishment and consolidation of a common market, the respect for fundamental rights, democracy and the rule of law are more firmly rooted.

The Treaty of Lisbon ${ }^{7}$ concerning fundamental rights, enhanced transparency, and greater opportunities for participation in policy-making. In respect to $\mathrm{EO}$, made possible to broaden the Ombudsman's mandate to include possible maladministration in the framework of the Common Foreign and Security Policy, including the Common Security and Defence Policy. ${ }^{8}$

It is significant that in respect of economic and commercial interests - rights to property, freedom to pursue a trade or profession - that the area of so-called fundamental rights protection was first developed by the CJ. The initial trigger for this development was the challenge to the supremacy of Community law from Member States, today, however there are different reasons for, and other consequences of the continuous expansion of the role of fundamental rights in EU law. The powers of the Community and Union have grown considerably, and the evolution of a more narrowly economic community into a broader social and political entity has continued with the CJ playing a self-conscious part in the process of federalizing or integrating the legal system of the Member States.

Rather, even though the Community was originally presented as an economic entity, its wider ambitions required that a human rights discourse ${ }^{10}$ be deployed as

\footnotetext{
${ }^{6}$ At this respect it is illustrative to mention that traditionally, Ombudsmen intervene in the application of laws and government programmes and, as required, try to ensure a certain degree of legality, fairness and reasonableness. Although some Ombudsmen are prevented by their constituent statutes from intervening, except in cases of flagrant "maladministration", many do not hesitate to propose legislative or regulatory reform measures and thereby play the role of reformers. In fact, some are explicitly authorised to do so. See: Jaсову, Daniel (1999): The future of the Ombudsman, In: The International Ombudsman Anthology, The Hague, Kluwer Law International, p. 34.

7 Treaty of Lisbon amending the Treaty on European Union and the Treaty establishing the European Community, signed at Lisbon, 13 December 2007/C 306/01

${ }^{8}$ The European Ombudsman, Annual Report, 2010, p. 16 available at: http://www.ombudsman.europa.eu/ activities/annualreports.faces

${ }^{9}$ Craig, Paul [and], De. BúrCA (1998): EU Law. Text, cases and materials. (USA, Oxford University Press, $2^{\text {nd }}$ Ed.) p. 298.

10 For the Discourse Principle, see also: Habermas (1998): Between Facts and Norms, Contributions to a Discourse Theory of Law and Democracy, (translated by Wiliam Rehg, Cambridge, Massachusetts, 1st Edition) pp. 118-131; The author points out that this principle is intended to assume the shape of a principle of democracy only by way of legal institutionalization. The principle of democracy is what then confers legitimating force on the legislative process.
} 
a necessary ideological addition to its 'proto-constitution' in conjunction with other concepts, such as democracy and the rule of law, the discourse of human rights was identified as providing both the ethical direction for the Community's actions and the constraints upon its interference in the sovereignty of its Member States. The language of human rights was thus used to authenticate the Community as a site of governance. ${ }^{11}$

The explicit concepts of inherence and integrality again indicate a retrospective representation of the formation of the Community as a system and structure that not only recognized fundamental rights but would have no credibility as an institution of governance in the modern world without their presence. ${ }^{12}$

In recent years, moreover, co-operation among the various Member States administrations and the EU institutions has continued to grow in scope and intensity, especially in fields related to security. ${ }^{13}$

In this respect, the European Ombudsman has always given high priority to the process of co-operation. ${ }^{14}$

In order to protect the rights of citizens and residents and provide them with effective remedies, co-operation among administrations needs to be matched by cooperation among Ombudsmen, who are well placed to intervene when EU law is not applied correctly by public administrations, so as to provide an effective remedy and help avoid similar failures in the future by educating and encouraging public authorities to apply EU law correctly. ${ }^{15}$

Most recently, the European Ombudsman's efforts to work closely with the EU institutions and bodies and with Ombudsmen throughout the Union have one overriding objective, namely ensuring an optimal service to citizens.

The European Ombudsman has two immediate challenges in terms of raising awareness: many people do not know what an Ombudsman is and many people do not know what the EU does. Any information that the EO produces must address these two

11 Williams (2004): EU Human rights policies. (Great Britain, Oxford University Press) pp. 128-129.

12 Williams (2004): p. 148.

${ }^{13}$ For example common migration policies have been on the Community agenda since the Single European Act of 1986 stipulated free movement of persons within its borders. Schengen Agreement initiated common internal borders in 1985 and has since been extended. Schengen provided for common provisions on visas, common immigration rules, and border control procedures. Co-operation was extended by the Dublin Convention, which removed the right of asylum-seekers to apply for asylum in more than one signatory State. Other resolutions deal with manifestly unfounded asylum applications and safe third countries. See: HarLow (1999). "Access to Justice as a Human Right: The European Convention and the European Union", In: Alston (1999): The EU and Human Rights (Great Britain, Oxford University Press) p. 210.

See also: Schengen Agreement of 14 June 1985 and on the gradual abolition of checks at common borders and Convention determining the State responsible for examining applications for asylum lodged in one of the Member States of the European Communities - Dublin Convention [OJ C 254 ] 19/08/1997 p. 0001 - 0012

${ }^{14}$ For the principle of co-operation see: CRAIG [and] DE BúrCA (2003): EU Law. Text, cases and materials. (Oxford, Oxford University Press) pp. 3-53; Micklitz (2005): The politics of judicial co-operation in the EU : Sunday trading, equal treatment and good faith, (Cambridge, Cambridge Univ. Press).

15 See: "Human rights and non-judicial remedies - The European Ombudsman's perspective"; Speech by the European Ombudsman, Professor P. Nikiforos Diamandouros, at the London School of Economics and Political Science, London, 30 November 2005 available at: http:/www2.lse.ac.uk/humanRights/events/ European_Ombudsman.aspx 
issues in a clear way to target potential complainants better and EU institutions should systematically inform people they are in contact with about their right to complain.

Because of the fact that the European Ombudsman offers a fast service and one that is free and flexible it is important to be unambiguous for those who fear negative repercussions from the institutions if they complain and to make clear that any attempt to disadvantage, or threaten to disadvantage, a person for exercising the right to complain to the EO would itself be maladministration. EU institutions and bodies should take the necessary steps to ensure that their officials are aware of this and act accordingly. ${ }^{16}$

\section{ORIGINS OF THE EUROPEAN OMBUDSMAN}

The idea behind the office of EO was to promote the concept of European citizenship ${ }^{17}$, so as to enhance relations between citizens and the European institutions.

In other words, as the First European Ombudsman has stated, the work of the Ombudsman should focus on helping European citizens and others entitled to address to the Ombudsman, to exercise their rights fully and, in so doing, to give the European Administration a more human face.

While the mandate of the European Ombudsman is confined to the Union level of governance, we might reasonably assume that it has been created under the broader framework non-judicial remedies for the protection of fundamental rights, encompassing the variety of national experiences in Europe and the spread of Ombudsmen institutions as a global phenomenon.

The idea of a European Ombudsman was launched already in the 1970s, the period of "Ombudsmania" in Western Europe, but was only realized with the Treaty on European Union in 1992. The European Ombudsman was intended to mitigate the serious democratic deficiencies of European governance, to prevent further alienation of the sceptical public from an anonymous administration "up there in Brussels", and to polish up the image of the EC/EU as a whole. Ever since, the enhancement of the relationship between the European administration and the citizen has been the raison $d$ 'etre of the European Ombudsman. ${ }^{18}$

\footnotetext{
${ }^{16}$ See: The European Ombudsman, Annual Report, 2005 and Annual Report 2005 Executive Summary and Statistics, p. 6.

Available at: http://www.ombudsman.europa.eu/activities/annualreports.faces

17 In regard to its citizens, the EU guarantees fundamental rights and freedoms along with citizenship of the Union, which is additional to national citizenship and entitles the right to move and reside freely within the territory of the Member States, the right to vote and stand as candidates in elections to the European Parliament and municipal elections in their Member State of residence, the right to enjoy diplomatic and consular protection, the right to petition the European Parliament, to apply to the European Ombudsman and the right to write to the Union's institutions and advisory bodies in any of the Constitution's languages and to obtain a reply in the same language. With aims similar to the Lisbon Treaty, was signed but never ratified. See: The Constitutional Treaty of 29 October 2004 [CT], Article I-10, C 310/14 Official Journal 16.12.2004

18 Peters (2005): “The European Ombudsman and the European Constitution", In: Common Market Law Review. (Netherlands, Kluwer Law International) No. 42, pp. 699-700
} 
The phenomena of "Ombudsmania" was due to the fact of the rapid spread of the Ombudsman institution is associated with two main developments.

The first is the rise of the welfare and regulatory state, which increased the size and complexity of public administration. The Courts are the principal mechanism through which citizens may assert their rights against the administration, but Ombudsmen offer an additional and less formal way to solve disputes. Their main advantages are zero cost to the complainant and more flexible procedures.

Most Member States of the European Union have an Ombudsman at the national level, the exceptions are Italy ${ }^{19}$, Germany and Luxembourg, in these countries it is established the right to petition before the Parliament on the national level. ${ }^{20}$

In connection with this right and independent of the variability of German petition organs, two things can result from the frequent application of Article 17: First, direct mediation can occur between the administration and the citizens with everyday problems. Second, an indirect effect can be achieved by influencing the political process, that is, disclosure of deficits and shortcomings in laws. Disclosure is the first step in possible correction in favour of the citizens. ${ }^{21}$

There are also Ombudsmen in the regions of Spain and Italy 22 and in some of the German Länder. The first that created an Ombudsman was Rhein-land-Pfalz in 1974, Mecklenburg-Vorpommern and Schleswig-Holstein followed in 1995.

It is also worthwhile the mention of a socio-psychological element, which permits the individual to present his petition personally to the Ombudsman and frequently to clarify the situation directly, gives the citizen the feeling that someone is there and willing

19 In Italy a Region may appoint a "Difensore Civico" competent to monitor the activities of the regional administration and of bodies dependent on it, based on articles 117 and 123 of the Constitution. See: Senato della Repubblica, Constitution of the Italian Republic, 27 December 1947; Publications Office of the Senate Service for Official Reports and Communication available at: kttp://www.senato.it/documenti/repository/ istituzione/costituzione_inglese.pdf. A national ombudsman - although not envisaged in the constitution could be created by a State law. In addition to a draft constitutional law amending the constitution, which provides for the insertion of Article 98a, establishing the office of State Difensore Civico, a number of draft ordinary state laws have been submitted with the aim of establishing the office. However, none of these drafts has resulted in a law being passed. Only the regions have created the office of regional Ombudsman (Difensore civico) under regional laws. Crespo Allen (2001): European Ombudsman and National Ombudsmen or similar bodies comparative tables (Luxembourg, European Parliament) 2001, p. 55.

20 Article 17 [Petition] provides: "Every person shall have the right individually or jointly with others to address written requests or complaints to competent authorities and to the legislature". See also Article 45b [Parliamentary Commissioner for the Armed Forces] and Article 45c [Petitions Committee] In: Basic Law for the Federal Republic of Germany 23 May 1949, (Federal Law Gazette, p. 1) (BGB1 III 100-1) most recently amended by "Basic Law for the Federal Republic of Germany in the revised version published in the Federal Law Gazette Part III, classification number 100-1, as last amended by the Act of 29 July 2009 (Federal Law Gazette I p. 2248) available at: http://bundesrecht.juris.de/englisch_gg/englisch_gg.html

21 Kempf (1996): “Ombudsmanship without an Ombudsman: Germany" In: The European yearbook of comparative government and public administration, vol. III: p. 333.

22 It can be seen that the "Difensore Civico" has reduced considerably the complaints of the citizens against the public administration, in the Regions where the office was created (especially in the Regions the North), See further: Matteis (2003): "Il Mediatore Europeo", In: Rivista Italiana di Diritto Pubblico Comunitario, vol. XIII No. 5, pp. 1191-1203 
to help. The anonymity of administrative decisions can be penetrated by personalization of the administrative control for the individual seeking advice. ${ }^{23}$

It may perhaps even become visible, since the consultant is not an anonymous group but a clearly identifiable person, these arguments can equally well be applied to the work of the European Ombudsman.

The second development is the global spread of aspirations to democracy and human rights. In countries which are in the course of transition to democracy, Ombudsmen have been established primarily to protect fundamental or human rights. This is the case, for example, in many countries of Latin America, Portugal, Spain and most of the new democracies of Eastern Europe. ${ }^{24}$

At this respect, the EO has stated that in the recent transitions to democracy in Central and Eastern Europe have led to a sharp increase in the number of Parliamentary Ombudsman Institutions. ${ }^{25}$

What should be established is that the key features that the Ombudsmen have in common are:

- The personal dimension of the office, built around a publicly-recognised officeholder, set up by or under statute;

- The independence of its work, autonomous of the bodies or people they investigate;

- Impartial: they are not 'on the side' of either the complainant or the respondent;

- Free and easy accessibility for the citizen, make no charge to complainants;

- A primary focus on the handling of complaints, having the power (not punitive) to award or recommend remedies for complainants;

- They might conduct their investigations in private and do not disclose the names of complainants in their published reports;

- A review function that includes legal rules and principles; principles of good administration and fundamental and human rights;

- A general mandate to supervise the entire reach of the public administration (but rarely extending to include the EU Courts);

\footnotetext{
23 Kempf (1996): p. 328.

${ }^{24}$ Harden (2000): "When Europeans complain. The work of the European Ombudsman”, In: The Cambridge Yearbook of European Legal Studies, (Oxford-Portland Oregon) Vol. III, p. 201.

25 The first Ombudsman in any of the former communist countries was actually established in Poland in 1988, before the fall of Berlin Wall. In Slovenia a Human Rights Ombudsman was envisaged in the Constitution of 1991. The extraordinary advance in the concept of the Ombudsman in this region was due to the fact that human rights were a guiding principle and a central issue of the democratic changes in this part of Europe, they supported the founding of this institution to resolve the problems of ordinary people on one hand and help the State to strengthen its democracy and the institutions underpinning the rule of law on the other. See: BizjaK (1998): "The role and experience of an Ombudsman in a new democracy", In: The International Ombudsman Yearbook. No. 2, pp. 57-58
} 
- A lack of power to issue binding decisions; and a distinct preference, instead, for working through use of persuasion, moral authority and, in some cases, the authority of the government or assembly by which the Ombudsman is appointed. ${ }^{26}$

\section{PROPOSALS FOR THE ESTABLISHMENT OF THE EUROPEAN OMBUDSMAN}

The Spanish Prime Minister Felipe Gonzalez introduced the idea of citizenship of the Union, in a letter of 4 May 1990 to the other members of the European Council. ${ }^{27}$

$\mathrm{He}$ also suggested the creation of appropriate mechanisms to protect the special rights that would belong to the status of European citizen. One of the possibilities foreseen was to establish a European Ombudsman ${ }^{28}$. In March 1991, drafts Treaty Articles on the appointment of an Ombudsman were submitted by the Danish delegation. ${ }^{29}$

The Danish proposal included a number of minor institutional changes of a practical nature, which maintained the existing institutional balance ${ }^{30}$, including the

26 See "The role of the Ombudsman in future Europe and the mandates of Ombudsmen in future Europe"; Speech by the European Ombudsman, Prof. P. Nikiforos Diamandouros, to the 9th Round Table meeting of European Ombudspersons and the Council of Europe Commissioner for Human Rights, Copenhagen, 31 March 2005.

In his visits to all the EU Member States, as well as to the candidate countries for EU membership have left him with the strong impression that Ombudsmen in Europe have, to a very considerable extent, these basic features in common. Important variations do exist, but in most cases these can be attributed to the particular context in which the Ombudsman operates, or to attempts to enhance the prototype model.

27 The proposal was originally influenced by two elements: the political approach of Felipe González to the integration process and the legal form of the Ombudsman in the 1978 Spanish Constitution.

28 The text proposed by the Spanish delegation is based on the note on citizenship it submitted in SN $3940 / 90$ of 24 September 1990. This proposal envisages a specific framework for the general aspects of European citizenship as one of the three pillars of the future Union and the foundation of its democratic legitimacy. The concept and content of citizenship are conceived of as having an evolving dimension and as being an element which should inform all the policies of the Union. For these reasons, and bearing in mind the conclusions of the European Council meeting on 14 and 15 December 1990 in Rome, it was suggested that the Treaty include a Title specifically devoted to a general framework for citizenship. No mention was made, although this is not ruled out, of possible specific treatments of citizenship in individual areas, some of which are already under examination in the Conference, particularly in the chapter on the extension of redefinition of jurisdiction, such as judicial co-operation, public health or the disclosure of information, to mention only a few of the abovementioned initiatives. The proposal has been annexed in full in: The European Ombudsman, Origins, Establishment and Evolution (2005) [on line] (Luxembourg: Office for Official Publications of the European Communities), available at: http://www.ombudsman.europa.eu/en/resources/ historicaldocument.faces/en/10122/html.bookmark; [last visited: 14 June 2011]

29 See: The European Ombusman, Annual Report, 1995 p. 4 and the Danish proposal for a European Ombudsman, 21.021991 stated the New Article 140 A: "The European Parliament shall appoint an Ombudsman empowered to receive submissions from physical or legal persons domiciled in a Member State concerning deficiencies in the administration of the institutions. Pursuant to the instructions, the Ombudsman shall conduct inquiries for which he finds grounds, either on the basis of submissions or on his own initiative. The Ombudsman shall submit an annual report to the European Parliament on the outcome of his inquiries."

30 The institutional balance, as an European constitutional principle, is to some extent a functional equivalent of the classic principle of separation of powers in State constitutions (checks and balances) to make all of its institutions more effective, in reality democratic accountability does lie first and foremost in the Council of 
proposal for a European Ombudsman. However, it proved to be at cross-purposes with the desire of many Member States for more far-reaching institutional reforms, particularly in terms of the decision-making process in the Council with regard to the internal market and the powers of the European Parliament. ${ }^{31}$

A favourable climate came about for the creation of this supranational body when two different ideas concerning the process of Community integration came together in the last decade of the $20^{\text {th }}$ century: the federalist perspective of the Belgian, Greek and Spanish governments, and the euro-scepticism of the Danish government.

The task of defining the legal model succeeded in this exceptional political climate, despite the strong reservations of the more supranational institutions, the European Parliament and the European Commission, which were unwilling or unable to see at the time how useful the new body would be in galvanising efficiency and democracy within the context of the European Union's unfolding institutional dynamic.

It is important to remember that the European Parliament, on the one hand, and the Commission headed by Jacques Delors, on the other, were not initially in favour of the establishment of a European Ombudsman. The former was in reality more concerned about reinforcing the right to petition (until then regulated only by the relevant provisions in its Rules of Procedure) and therefore believed that the creation of an European Ombudsman's office might substantially weaken this parliamentary prerogative. The Commission, however, was most worried about the risk of establishing the umpteenth body at the request of the Member States to monitor further its activities, and particularly in this instance, its administrative activities. As a result, the Commission invoked the principles of subsidiarity and proximity and formally recommended the creation of a European Ombudsman's office, but at the Member State rather than at the EU level. ${ }^{32}$

The Commission therefore attempted a diversionary tactic, proposing a system of organised co-operation among national Ombudsmen rather than the establishment of the European Ombudsman. It feared that the establishment of the EO would impose additional resource-intensive duties on the Commission, particularly in terms of producing answers and obtaining information relating to the long series of questions an Ombudsman would be likely to pass on to the Commission concerning the execution

\footnotetext{
Ministers (citizens expect their Head of Government and Ministers to look after their national interests). The doctrine has said that it is difficult to identify the executive powers in the EU, either at the Constitution especially because it is composed among the variety of Member States of the EU and the balance should be seek between its intergovernmental and supranational forces.

31 Biering (2005): “The Danish Proposal to the Intergovernmental Conference on Political Union”, In: The European Ombudsman, Origins, Establishment and Evolution, [on line] (Luxembourg: Office for Official Publications of the European Communities) p. 40.

Available at: http://www.ombudsman.europa.eu/en/resources/historicaldocument.faces/en/10122/html. bookmark [last visited: 14 June 2011]

32 Perillo (2005): “The Process of Drafting the European Ombudsman's Statute", In: The European Ombudsman, Origins, Establishment and Evolution, [on line] (Luxembourg: Office for Official Publications of the European Communities) p. 56, Available at: http://www.ombudsman.europa.eu/en/resources/ historicaldocument.faces/en/10122/html.bookmark; [last visited: 14 June 2011]
} 
of its duties. The Commission was also critical of the European Parliament's right, confirmed in the Treaty, to appoint ad-hoc Committees of Inquiry and to receive complaints (the right of petition). However, this idea met with limited sympathy among the Member States, especially since the resulting powers of control would be neither visible nor effective. ${ }^{33}$

A telling point we can make here is that later it was the responsibility of the Commission, in a broad vision of its role as Guardian of the Treaties, to arrange matters in such a way that this new institution could operate as effectively as possible. ${ }^{34}$

It had to demonstrate openness without upsetting the institutional balance. It was important that relations between the Commission, the most frequent target of complaints from citizens, and the European Ombudsman, the defender of the people of Europe, were crowned with success. ${ }^{35}$

Sending the text of this Inter-institutional Agreement to the Directors General and Heads of Service, the Secretary General summarised as follows the internal procedure that was yet to be established: "In the case of a referral to the Commission by the Ombudsman, Directorate E of the Secretariat General will ask for a draft response from the Directorate General or service concerned. The Commission's opinion will be formally issued by the Secretariat General with the agreement of the Legal Service, under the authority of the President and the competent Commissioner, who will be duly authorised".

This note lays down the substance of the two essential principles characterising the Ombudsman procedure: authorisation and sub delegation. ${ }^{36}$

While the Spanish Government contributed to the eventual success of the creation of the Ombudsman, this was more due to the existence of political will favouring creation of the institution rather than to the legal feasibility of the model set out in the Spanish proposals to the Intergovernmental Conference.

\footnotetext{
33 Biering (2005): p. 47.

34 See: Interinstitutional Agreement of 29 October 1993, Official Journal, 7 December 1993 [OJ C 331]

These rules relate to interinstitutional cooperation in general and to more specific problems (classification of expenditure, the matter of legal bases, incorporation of financial provisions in legislative acts, etc.) which had not been resolved by the 1993 agreement or which were dealt with under other arrangements (agreements or joint declarations) agreed between the institutions. The agreement strengthens interinstitutional collaboration.

Trialogue meetings (between the President of the Council (Budget), the Chairman of Parliament's Committee on Budgets and the Member of the Commission with responsibility for the budget), generally followed by conciliation between the Council and a delegation from Parliament with the Commission as a participant, are planned in accordance with the following schedule: before the establishment of the preliminary draft budget by the Commission; before the establishment of the draft budget by the Council; before the first reading by Parliament; after the first reading by Parliament and the day preceding the second reading in the Council. Available at: http://europa.eu.int/scadplus/leg/en/lvb/l34003.htm

35 Eecкhout [and] Godts (2005): “The European Commission's Internal Procedure for Dealing with the European Ombudsman's Inquiries”, In: The European Ombudsman, Origins, Establishment and Evolution, [on line] (Luxembourg: Office for Official Publications of the European Communities) p. 167.

http://www.ombudsman.europa.eu/en/resources/historicaldocument.faces/en/10122/html.bookmark; [last visited: 14 June 2011]

36 Eeckhout [and] Godts (2005): p. 168.
} 
According to Moreiro, he notes that the Spanish proposal had the significant merit of anticipating a model of Ombudsman which would have been ideal if implemented at a more advanced stage in the process of political integration. It was a maximalist but not very pragmatic proposal in terms of clarifying the Ombudsman's powers and the political context in which it was formulated. This was perhaps the reason for opting for the minimalist proposal advocated by the Danish delegation, which only gave the EO competence to inquire into possible instances of maladministration in the activities of Community institutions and bodies. ${ }^{37}$

In the original Spanish proposal that was presented as part of the negotiations leading to the Treaty on European Union, the European Ombudsman was meant to supervise the application of the European citizens' rights, also on the national level. In the compromise adopted at Maastricht, based on a Danish proposal, the Ombudsman's remit was limited to the possible maladministration in the activities of the Community institutions and bodies. ${ }^{38}$

Agreement was finally reached to include the right to apply to the European Ombudsman, alongside the right to petition the European Parliament, in the part of Treaty establishing citizenship of the Union.

According to the EC Treaty, the role of the European Ombudsman was to strengthen the relationship of trust between the citizens and the institutions, thus making the actions and functioning of the Community's administration more focused on the citizens' needs and more transparent and accessible in their eyes. ${ }^{39}$

From that point of view, the Ombudsman's role could not overlap with other existing resources aimed at protecting citizens' interests and rights, such as the right to petition, access to documents, the right to contact the European Commission or even the various channels of appeal involving the EU Courts. The tasks of this new body had quite simply been conceived as the legitimate complement to these traditional instruments for civic and legal progress. They provided all EU citizens, regardless of their traditions, with an additional way of interacting with the Community's administration both informally, and with the assistance of a body endowed with the necessary authority .

The European Ombudsman was formally agreed by the European Parliament, for daily purposes with this denomination. The first holder of the office, Mr Jacob Söderman of Finland, was appointed in July 1995. When Mr Söderman decided to retire before the end of his second term of office, Mr Nikoforos Diamandouros of Greece took over the position in April 2003. He was twice re-elected by the European Parliament on 11 January 2005 and 20 January 2010 for the next five years.

\footnotetext{
37 Moreiro GonzÁlez (2005): "The Spanish Proposal to the Intergovernmental Conference on Political Union", In: The European Ombudsman, Origins, Establishment and Evolution, [on line] (Luxembourg: Office for Official Publications of the European Communities) p. 36.

http://www.ombudsman.europa.eu/en/resources/historicaldocument.faces/en/10122/html.bookmark; [last visited: 14 June 2011]

38 SöDERMAN (1997): "A thousand and one complaints: The European Ombudsman en route", In: European Public Law, vol. III No. 4, p. 359.

39 Perillo (2005): p. 54.
} 


\section{ROLE OF THE EUROPEAN OMBUDSMAN}

The European Ombudsman can be categorized generally as one of the external accountability mechanisms of the supranational EU. In particular, the European Ombudsman is the only example of a fully-fledged, classical Ombudsman ${ }^{40}$ at the international level.

It was created in an attempt to reduce the democratic deficit in the EU, by improving the channels for persons living in any of the EU Member States to voice their complaints over EU governance, and by increasing the EU's transparency and accountability. The $\mathrm{EO}$ addresses instances of Community maladministration, thereby improving good governance on the part of the Community institutions and bodies. Also, human rights matters fall within his jurisdiction and, thus, the office can and does contribute to the EU's observance of human rights. ${ }^{41}$

His work has a dual dimension. On the one hand, the Ombudsman acts as an external mechanism of control, investigating complaints about maladministration and recommending corrective action where necessary. On the other hand, the Ombudsman serves as a resource to the institutions, helping them to better their performance by directing attention to areas for improvement. The ultimate goal in both instances is to improve the service provided to European citizens with an alternative system of nonjudicial appeal to guarantee legal action and access to justice.

The EO, whose decisions and recommendations are not legally binding and do not constitute coercive measures, still can be called on to seek amicable solutions wherever possible in the cases he deals with.

The EO -by definition- shares at least one common feature with all the rest of Ombudsmen: its rulings and recommendations are legally non-binding.

In spite of the fact that the statutory powers of the Ombudsman may vary from country to country ${ }^{42}$ and from office to office, we can said that the defence of fundamental rights it is also included in the guideline of the EO.

\footnotetext{
40 The European Ombudsman can be included in Professor D.C. Rowat's classic definition of the office of Ombudsman: First the Ombudsman is an independent and non-partisan officer of the legislature who supervises the administration; Second, he deals with specific complaints from the public against public administrative injustice and maladministration; and Third, he has the power to investigate, criticise and publicise, but not to reverse, administrative action. See: Rowat (1973): El Ombudsman: el Defensor del Ciudadano. (México, Fondo de Cultura Económica) 462 pp.

${ }^{41}$ C. ReIf (2004): The Ombudsman, Good Governance and the Internacional Human Rights System, (Martinus Nijhoff Publishers, Leiden) p. 367.

42 There are certain legal contrasts and differences between the Nordic and the Spanish Ombudsman. A remarkable difference is for example that the Ombudsman was brought into the Spanish system mainly to defend the rights of citizens, a circumstance which has had a direct bearing on his actions. Another substantial difference is that at State level the "Defensor del Pueblo" has the power to lodge appeals of unconstitutionality before the Constitutional Court and is deeply involved in the task of legislative promotion and mediation activities in topics such as violence against women, the illegal immigration ("pateras" crossing the Mediterranean Sea) environmental and health issues. See: Reports and documents from "El Defensor del Pueblo Español" in: http://www.defensordelpueblo.es/en/index.html
} 
The EO forms part of the institutional balance, although he is not mentioned as an institution or other body in Articles 7, 8, 9 (former EC Treaty). ${ }^{43}$

The institutional balance, as European constitutional principle, is to some extent a functional equivalent of the classic principle of separation of powers in State constitutions: it contributes to the realization of checks and balances, and thereby ultimately promotes the control of power to the benefit of the citizens. But the EU has both federal (Bundesstaat) and con-federal features (Staatenbund). It is not to be compared to a national State either. The EU has the basic functions of the legislative, the executive and the judiciary powers but in a new institutional composition. The Commission is not a government. The Council and the Parliament do not constitute a two chamber system as we know it from Member States. The institutional balance and strengthen the EU by making all of its institutions more effective. Although democratic legitimacy should reside in many different parts of the EU's structures, most likely none of the institutions would seem to acquire sufficient sovereignty and credibility concerning the others to take up the task of continuous administrative reform and control, partly to sustain the inter-institutional balance.

In the Treaty's institutional part (Part Five "Institutions of the Community") the EO figures in the section on the European Parliament Article 228 of the (EC Treaty). This systematic position has remained the same in the Treaties. ${ }^{44}$

Actually, the Treaty of Lisbon regulates the election of the European Ombudsman by the European Parliament and the Ombudsman's independence principle, which corresponds to Article 228 of the Treaty on the Functioning of the European Union $(T F E U)^{45}$ (former Article 195 of the EC Treaty), which includes a provision for the Statute to become an European law of the European Parliament. ${ }^{46}$

\footnotetext{
43 Articles I-19, I-30, and III-393 [corresponding article of the Treaty establishing a Constitution for Europe [CT], 29.10.2004] Treaty establishing the European Community [hereinafter EC Treaty]; (Rome, 25.3.1957, lastly amended by the Accession Treaty 2003) Consolidated version (applicable as from 1.11.2004)

${ }^{44}$ Now Article 228 (TFEU) was former Article III-335 of the Constitution [CT] Part Three, Title VI, and Chapter I "Provisions Governing the Institutions", Section 1 on the institutions, Subsection. 1 "The European Parliament". See: Peters, Anne. The European Ombudsman and the European Constitution. In: Common Market Law Review. (Netherlands). No.42, 2005, p. 711.

${ }^{45}$ European Union (2010): Consolidated Treaties and Charter of Fundamental Rights, (Luxemburg, Publications Office of the European Union).

46 This shows how many achievements have been done by the work that the European Ombudsman, it must be acknowledge that Söderman some years ago expressed his aspiration as an observer at the European Convention, he tried to promote that the right to petition the European Parliament and the right to complain to the Ombudsman should be enshrined in the main part of the future Constitution. He also proposed that all citizens' remedies under Community law should be mentioned in the Constitution, as well as the principles of openness and good administration and that the EU should have the capacity to adhere to any international human rights treaty. Furthermore, the Charter of Fundamental Rights should be binding within the scope of EU law.

See: Speech by the European Ombudsman, Mr Jacob Söderman to the Committee on Petitions concerning the presentation to the European Parliament of his Annual Report for 2002: Brussels 24 March 2003;

Available in: http://www.euro-ombudsman.eu.int/speeches/en/default.htm
} 
It was said that since its creation the EP wanted to grant the European Ombudsman the right to obtain all the information needed to carry out his task in line with the requirements of transparency. ${ }^{47}$

At this respect, the Inter-institutional Conference on 7 June 1993 primarily dealt with the EO and more generally with the issues transparency, democracy and subsidiarity. ${ }^{48}$

With regard to the secrecy/confidentiality issue, the EP -contrary to the Commission and the Council ${ }^{49}$ - preferred the term secrecy because most Commission documents are labelled as confidential which would exclude them from any scrutiny by the European Ombudsman. ${ }^{50}$

As a matter of practical consideration it can be seen that none of the existing institutions or bodies would appear to be technically suited to affect the kind of flexible norm-development which may be introduced by the European Ombudsman. The EU institutions are apparently unable to provide suitable control and reform mechanisms. ${ }^{51}$

The EU constitutional framework could provide a new impetus for fundamental rights, which must be fully asserted and observed following the broadening of the Union's competences. Also if the implementation of fundamental rights should be a goal of all European policies and that a "comprehensive and coherent" strategy 52 was needed for this leads one to suppose that it is in full agreement to the original purpose of the European

47 Official position of the European Parliament, Texts adopted: Resolution on the outcome of the Copenhagen European Council meeting of 21-22 June 1993 [B3-0947/93]

48 Conférence interinstitutionnelle, Lundi 7 Juin 1993, Luxembourg, Compte Rendu Analytique des Débats, PE 205.271. in: Eiselt [and] Slominski (2004): The Negotiation of the Interinstitutional Declaration on Democracy, Transparency and Subsidiarity, (Austria, Working Paper Nr: 4, (EIF) Institute for European Integration Research) p. 12, Available at: http://www.eif.oeaw.ac.at/downloads/projekte/wp4.pdf [last visited: 15 June 2011]

49 For the question as the question as to whether the Council should meet publicly when is sitting in its legislative capacity its proceedings should be open to the public (like the proceedings of the EP), the European Ombudsman has stated that all that needs to be done in order to open all such meetings to the public would therefore be for Council to amend its Rules of Procedure. In the EO's view, the Council's failure to do so constitutes an instance of maladministration. See: Special Report from the European Ombudsman to the European Parliament following the draft recommendation to the Council of the European Union in complaint 2395/2003/GG; The Report recommended that the Council should review its refusal to decide to meet publicly whenever it is acting in its legislative capacity.

${ }^{50}$ Eiselt [and] Slominski (2004): p. 12.

See further: Regulation (EC) No 1049/2001 of the European Parliament and of the Council of 30 May 2001 regarding public access to European Parliament, Council and Commission documents, [OJ 2001 L 145 p. 43]; Summary of decision on complaint 2066/2004/TN against the European Commission. In his decision, the Ombudsman took the view that, in the overall scheme of Regulation 1049/2001, the right of citizens to apply for access to a document that has not been made public and to contest an eventual refusal of a confirmatory application provides the primary mechanism to guarantee the widest possible access to documents.

51 See further: Gjerloeff Bonnor (2000): "The European Ombudsman: a novel source of soft law in the European Union”, In: European Law Review, vol. XXV, pp. 40-41.

52 See: Procedure File of the European Parliament; Reference INI/2005/2007; Title: Promotion and protection of fundamental rights: the role of national and European institutions including the Fundamental Rights Agency; Legal Basis REG 045. 
Ombudsman (the control of the administration of the European Institutions) and did not intend to replace this purpose with a different one (the protection of fundamental rights, not concurrent to the control of the Administration).

The EO also promoted the application of the Charter of Fundamental Rights, most notably through inquiries on issues such as the fundamental right to good administration, including the important principle of fairness, the rights of persons with disabilities, and the right of access to documents. ${ }^{53}$

Concluding, his tasks to promote fundamental rights and to follow the development of the implementation of the Charter of Fundamental Rights within the European Union should be seen in a proactive support to human rights policy-making in two ways: by identifying where legislative improvements would be most welcome and by monitoring the implementation and enforcement of existing legislation.

At this stage and before new organisations are set up to defend fundamental rights, the European Ombudsman cannot concentrate exclusively on supervising the administrative activities of the institutions and improving their practices and efficiency, but must also eagerly include the enhancement of the protection of human rights as part of his faculties.

\section{LEGAL FRAMEWORK OF THE EUROPEAN OMBUDSMAN}

The European Ombudsman was finally established in 1993 following the Treaty of Maastricht, which also established the European Union and the European Citizenship. European citizen's right to apply to the Ombudsman was then recognized (former Articles 21 and 195 of EC Treaty). ${ }^{54}$

Why is the context to the European citizenship so important? As it has been stated in the Intergovernmental Conference held in Nice in December 2000, within the European Union, the European institutions must be brought closer to its citizens. Citizens undoubtedly support the Union's broad aims, but they do not always see a connection between those goals and the Union's everyday action. They want the European institutions to be less unwieldy and rigid and, above all, more efficient and open. Many also feel that the Union should involve itself more with their particular concerns, instead of intervening, in every detail, in matters by their nature better left to Member States and regions elected representatives. This is even perceived by some as a

\footnotetext{
53 See: The European Ombudsman (2010). Overview 2010, p. 3.

Available at: http://www.ombudsman.europa.eu/en/activities/annualreports.faces

It states that transparency constituted the most significant category in terms of the subject matter of inquiries, with $33 \%$ of all inquiries concerning this issue.

54 See: Treaty establishing the European Community [hereinafter EC Treaty]; (Rome, 25.3.1957, lastly amended by the Accession Treaty 2003) Consolidated version (applicable as from 1.11.2004) [corresponding article of the Treaty establishing a Constitution for Europe, 29.10.2004]
} 
threat to their identity. ${ }^{55}$ More importantly, however, they feel that deals are all too often cut out of their sight and they want better democratic scrutiny. ${ }^{56}$

The Ombudsman's work is carried out in accordance with Article 228 (TFEU), as well as Article 14 of the Statute of the Ombudsman and the implementing provisions adopted by the Ombudsman ${ }^{57}$; the Statute and the implementing provisions ${ }^{58}$ adopted by the EO under Article 1459, are still in accordance with Rule 179 of the Rules of Procedure of the European Parliament, the implementing provisions are annexed, for information, to Parliament's Rules of Procedure. ${ }^{60}$

The mandate empowers him to receive complaints from any citizen of the Union or any natural or legal person residing or having its registered office in a Member State, concerning instances of maladministration in the activities of Community institutions and bodies with the exception of the Court of Justice and the Court of First Instance acting in their judicial role.

55 The most striking example yet of voter's disillusionment with the EU was the fact that the citizens in France and the Netherlands that voted not to ratify the Constitution for Europe. An added complication is that voter turnout at European elections continues to decline, and the Union is still struggling to address the perception that it is a remote bureaucracy built by political elite.

56 See: Laeken Declaration of 15 December 2001 on the future of the European Union, [OJ C 364 ] 18.12 2000.

Part III of the Declaration concerns the convening of the Convention "composed of the main parties involved in the debate on the future of the Union to consider the key issues arising for the Union's future development and try to identify the various possible responses". The Praesidium of the Convention will be composed of the Convention Chairman and Vice-Chairmen and nine members drawn from the Convention (the representatives of all the governments holding the Council Presidency during the Convention, two national parliament representatives, two European Parliament representatives and two Commission representatives). Three representatives of the Economic and Social Committee with three representatives of the European social partners; from the Committee of the Regions: six representatives (to be appointed by the Committee of the Regions from the regions, cities and regions with legislative powers), and the European Ombudsman will be invited to attend as observers. The Presidents of the Court of Justice and of the Court of Auditors may be invited by the Praesidium to address the Convention.

57 In June 2008, the European Parliament adopted a decision revising the Ombudsman's Statute, with effect from 31 July 2008.

European Parliament Decision 2008/587 of 18 June 2008, amending Decision 94/262 on the regulations and general conditions governing the performance of the Ombudsman's duties, [OJ 2008 L 189, p. 25]

58 On 3 December 2008, the Ombudsman revised his implementing provisions in order to reflect the June 2008 changes to the Statute and to take account of experience gained since 2004, when the provisions were last changed. The new implementing provisions came into force on 1 January 2009.

59 See: Decision of the European Ombudsman adopting implementing provisions. Adopted on 8 July 2002 and amended by decision of the Ombudsman of 5 April 2004.

Available at: http://www.euro-ombudsman.eu.int/lbasis/en/provis.htm\#ref2

The implementing provisions under Article 14, deal with the internal operation of the Ombudsman's office. However, to make them understandable by and useful to citizens, they also include certain material relating to other institutions and bodies that is already contained in the Statute. The current implementing provisions came into effect on 1 January 2003.

${ }^{60}$ Decision of the European Parliament on the regulations and general conditions governing the performance of the Ombudsman's duties, adopted by the Parliament on 9 March 1994 [OJ L 113, 4.5.1994, p. 15] and amended by its decision of 14 March 2002 deleting Articles 12 and 16 [OJ L 92, 9.4.2002, p. 13] and Council Decision of 7 February 1994 approving the Decision of the European Parliament on the regulations and general conditions governing the performance of the Ombudsman's duties (94/114/ECSC, EC, EURATOM). 
It is undoubtedly that the role of the EO it is important in the provision of redress where maladministration has occurred and is able to investigate complaints where it is alleged that an injustice has been caused to the complainant as a result of maladministration by any of the Institutions of the European Community following the exceptions we have mentioned before.

The EO notes that the Treaty of Amsterdam has explicitly introduced the concept of openness into the Treaty on European Union, by stating that "This Treaty marks a new stage in the process of creating an ever closer union among the people of Europe, in which decisions are taken as openly as possible and as closely as possible to the citizen"61

With this regard, the EO considers that, in order to bring the administration closer to the citizens and to guarantee a better quality of administration, a Code which contains the basic principles of good administrative behaviour for officials when dealing with the public is necessary. ${ }^{62}$

Such a Code is useful for both the Community officials, as it informs them in a detailed manner of the rules they have to follow when dealing with the public, and the citizens, as it can provide them with information on which principles apply in the Community administration and on the standard of conduct which they are entitled to expect in dealings with the Community administration. ${ }^{63}$

Originally, the mandate was limited to the European Community, but the Treaty of Amsterdam brought the Union's "third pillar"64 (that is, police and judicial co-operation in criminal matters and, in particular, Europol) under the Ombudsman's supervision.

\footnotetext{
${ }^{61}$ Article 1 (TEU) [ OJ C 325/5, 24.12.2002]

${ }^{62}$ A clear example of this can be founded in: Special Report from the European Ombudsman to the European Parliament following the draft recommendation to the Council of the European Union in complaint 2395/2003/GG. The European Ombudsman stated that Article 1 (2) TEU clearly indicates that decisions in the European Union should be taken "as openly as possible". Article 1 (2) TEU thus unambiguously points the direction in which the Union and its institutions are to develop. There is thus no discretion or political choice to be made by the Council as regards this direction. However, the Council has not put forward any objective reasons to explain why the Council should be unable to move in that direction and open its meetings in a legislative capacity to the public. Second, as regards the process towards achieving that aim, time is an important factor. The Ombudsman therefore considers that the analysis cannot limit itself to the provisions that were introduced by the Treaty of Amsterdam but has to take into account subsequent developments. In this context, it is important to note that the Council itself, in the new Rules of Procedure adopted in 2000, introduced rules that provided for an increased openness of its meetings as a legislator. In the Ombudsman's view, the Council thus made clear that steps to increase the transparency of its legislative activity had to and could be taken. The adoption of the new Rules of Procedure in 2000 also confirms that doing so was and is possible under Community law as it presently stands.

63 See: Draft recommendation of the European Ombudsman in the own initiative inquiry, 13.09.1999 $[\mathrm{OI} / 1 / 98 / \mathrm{OV}]$

64 The Treaty of Maastricht (TEU) introduced the three-pillar structure (the Economic and Social Policy pillar, the Common Foreign and Security Policy or CFSP pillar, and the Justice and Home Affairs pillar). The CFSP pillar was built on the foundation of European Political Cooperation (EPC), but brought it under a treaty and extended it. The JHA pillar introduced cooperation in law enforcement, criminal justice, civil judicial matters, and asylum and immigration.
} 
Lately, in July 1999, the European Ombudsman recommended a draft Code of Good Administrative Behaviour to the Community institutions and bodies in the context of his own-initiative inquiry into the subject. ${ }^{65}$

The European Parliament has approved a slightly revised version of the Ombudsman's draft ${ }^{66}$ and called on the Ombudsman to apply the Code in examining whether there is maladministration, so as to give effect to the citizen's right to good administration in Article 41 of the Charter of Fundamental Rights of the European Union.

As a result of the Ombudsman's initiative, on 6 September 2001, the European Parliament adopted a resolution approving a Code of Good Administrative Behaviour which European Union institutions and bodies, their administrations and their officials should respect in their relations with the public. ${ }^{67}$

The EO will therefore take into account the rules and principles contained in the Code in his inquiries under Article 228 (TFEU) into possible instances of maladministration in the activities of the European Union institutions and bodies.

The Code contains the rules and principles which European Union institutions and bodies, their administrations and their officials should respect in their relations with the public.

It informs citizens of what they have a right to expect from the administration and officials of how they should behave in dealing with the public.

From the process of his own-initiative inquiry mentioned above, the EO is aware that most Community institutions and bodies have already adopted codes in various forms and, in many cases, the Code was recommended by the Ombudsman. The adoption of such codes has been a positive development for both citizens and civil servants. Afterwards in relation with the Status of the Code, the Charter of Fundamental Rights of the European Union, proclaimed at the Nice summit in December 2000 has now become legally binding as the Treaties. ${ }^{68}$

The Charter includes as fundamental rights of Union citizenship the right to good administration (Art. 41) and the right to complain to the European Ombudsman against maladministration by the Union's institutions and bodies (Art. 43).

In relation with the commitment to a legally binding Charter, contained in the Treaty of Lisbon, reflects a growing realisation that citizens should be placed at the centre

65 See: Draft recommendation of the European Ombudsman in the own initiative inquiry, 13.09.1999 [OI/1/98/OV]

${ }^{66}$ See: European Parliament resolution on the European Ombudsman's Special Report to the European Parliament following the own-initiative inquiry into the existence and the public accessibility, in the different Community institutions and bodies, of a Code of Good Administrative Behaviour [C5-0438/2000 2000/2212 (COS)]

${ }^{67}$ The European Code of Good Administrative Behaviour, p. 6.

Available at: http://www.ombudsman.europa.eu/resources/code.faces

${ }^{68}$ Charter of Fundamental Rights of the European Union proclaimed in Strasbourg on 12 December 2007 by the European Parliament, the Council and the Commission. Pursuant to the first subparagraph of Article 6 (1) of the Treaty on European Union, the 2007 Charter has the same legal value as the Treaties See: European Union (2010): Consolidated Treaties and Charter of Fundamental Rights, (Luxemburg, Publications Office of the European Union) 
of Europe's concerns. From the Ombudsman's perspective, the Charter is groundbreaking in recognising, for the first time, the right to good administration as a fundamental right of Union citizenship. ${ }^{69}$

\section{SCOPE OF THE CODE OF GOOD ADMINISTRATIVE BEHAVIOUR}

The purpose of the Code is to explain in more detail what the Charter's right to good administration should signify in practice. ${ }^{70}$

When the Code was approved, the European Parliament called on the European Commission to submit a proposal for a regulation containing the Code. The view was that a regulation would emphasise the binding nature of the rules and principles contained therein and apply uniformly to all EU institutions and bodies, thereby promoting transparency and consistency.

This goal could now best be achieved on the basis of a proposal from the Commission for a European law on good administration. Article 298 of the Treaty of Lisbon could provide the legal basis for such a law.

It states that:

"In carrying out their missions, the institutions, bodies, offices and agencies of the Union shall have the support of an open, efficient and independent European administration.

2. In compliance with the Staff Regulations and the Conditions of Employment adopted on the basis of Article 336, the European Parliament and the Council, acting by means of regulations in accordance with the ordinary legislative procedure, shall establish provisions to that end" ${ }^{71}$

The EO will continue to emphasise the added value of transforming the Code into European law. This would help eliminate the confusion currently arising from the parallel existence of different codes for most EU institutions and bodies ${ }^{72}$ and ensure that the institutions and bodies apply the same basic principles in their relations with citizens and would underline, for both citizens and officials, the importance of such principles.

More specifically, the Code explains to citizens what they have the right to expect from the Community administration. It equally serves as a useful guide for civil servants or officials on how they should behave in their relations with the public, not only

69 The European Ombudsman, Annual Report, 2007, p. 9.

Available at: http://www.ombudsman.europa.eu/activities/annualreports.faces

70 This section is primarily based on The European Code of Good Administrative Behaviour 2005.

Available at: http://www.ombudsman.europa.eu/resources/code.faces

${ }^{71}$ Consolidated Version of the Treaty on the Functioning of the European Union (TFEU); 9.5.2008, Official Journal [C 115/47)]

${ }^{72}$ For instance, the European Parliament adopted a report by 426 votes in favour, 3 against, with 9 abstentions on the European Ombudsman's activities in 2004. MEP's call on the EU institutions to adopt a harmonised code of good administrative behaviour. The resolution welcomes the efforts to give the Ombudsman's work a higher media profile, believing this could help reduce the number of complaints received which fall outside his remit. In 2004, almost $75 \%$ of complaints lodged fell outside the Ombudsman's remit as they did not concern a Community institution or body.

In addition, the House calls on the Ombudsman to define more precisely the concept of "maladministration", drawing up a strict and exhaustive list of institutions and bodies covered and categorically excluding all complaints which fall under the responsibility of the Member States' authorities. 
encouraging the highest standards of administration but also thereby avoiding instances of maladministration.

A new edition of the Code was published in 24 languages in 2005. Over 100000 copies were distributed throughout Europe and beyond. In response, national administrations and local authorities, schools and universities, training centres and public libraries, along with individual citizens, asked for copies for further distribution. This truly is a European success story. The Code has been adapted for national, regional and local administrations from Portugal to Italy, from Wallonia to Greece, and from Romania to Croatia. In light of the fact that the European Code has been taken on board by such a range of administrations throughout Europe the European Ombudsman continues to hope that it can be adopted by all EU institutions and bodies, perhaps in the form of an inter-institutional agreement. ${ }^{73}$

Finally, in reference to soft law methods there are two primary features of an ombudsman's soft law techniques, both related. First, the European Ombudsman may in individual cases adopt a soft law discourse simply to avoid legalistic counter-arguments by the administration's legal services (who in some administrations have a considerable general influence). By doing so, he not only obtains greater freedom to formulate norms, but may also increase his chances of compliance. Secondly, he may attempt to set in motion a soft law process which aims to procure an impact through either a generalisation of the soft norms formulated, or even a "crystallisation" of the soft norms into hard law (which may happen via legislation or judicial case law, or even be attempted in the ombudsman's practice itself). ${ }^{74}$

We may conclude that the Code, became binding as an inter-institutional code of conduct, providing greater consistency and equality on the Union's institutions actions towards assuring that democratisation and fundamental rights as settled in the Treaty of Lisbon, as the former Constitution was considered soft law, a rule of conduct that has not a legal binding force but which nevertheless may have practical effects. ${ }^{75}$

\section{FUNCTIONS OF THE EUROPEAN OMBUDSMAN}

The work of the EO primarily relates to the implementation of government policy. This type of administrative action is of great importance and affects the daily life of most citizens. Bureaucracies may produce unwelcome decisions and administrative failures. But what exactly is 'unwelcome' and what do we mean by administrative 'failure'? What, in other words, is our yardstick in assessing the quality of administrative action? ${ }^{76}$

\footnotetext{
73 The European Ombudsman, Annual Report, 2005, p. 18.

Available at: http://www.ombudsman.europa.eu/activities/annualreports.faces

74 Gjerloeff Bonnor, Peter (2000): p. 45.

75 For the concept of soft law see: SNYDER (1994): "Soft Law and Institutional Practice in the European Community", In The Construction of Europe: Essays in Honour of Emile NOEL (ed. Stephen D. Martin, Kluwer, Deventer), pp. 197-225.

76 Hertogh [and] Oosting (1996): "Introduction: The Ombudsman and the quality of government", In: The European yearbook of comparative government and public administration. vol. III, p. 260.
} 
In assessing the role of the Ombudsman with regard to the quality of government, the criteria applied need to be studied further. Indeed, it has been suggested that the use of concepts of administrative quality presents similar problems of definition. ${ }^{77}$

What would be established is that the task of the EO consists of addressing issues of 'maladministration' his role is much dependent on the definition given to the concept. But as with different ombudsman traditions, it seems that there are at least three basic views regarding the meaning of maladministration. First, it can be defined as illegality. Secondly, maladministration and illegality can be considered mutually exclusive, making maladministration undesirable but still lawful action. Thirdly, maladministration can be regarded as including illegality but having a wider scope. ${ }^{78}$

It is clear that improving the quality of administration and thereby enhancing relations between the Community and European citizens depends in large part on the administration itself. ${ }^{79}$

Neither Articles 226 and 228 (TFEU) nor the Statute of the European Ombudsman ${ }^{80}$ define the term maladministration, this has raised the question of whether the frequent application of open-ended principles of good administration may even influence the development and application of recognisable legal rules and principles, a question that has been much debated in this particular field.

It is clear that the core of the European Ombudsman mandate is represented by the legal concept of maladministration, which limits the European Ombudsman's jurisdiction as to the question to be determined. The concept of maladministration was previously unknown to Community law. ${ }^{81}$

As we mentioned, the EC Treaty does not contain a definition of the term 'maladministration' only Article 195 (EC Treaty) entrusts the Ombudsman with the task of examining cases of maladministration in the activity of the Community institutions and bodies.

In his first Annual Report in 1995, the European Ombudsman addresses a number of different meanings of maladministration as a criterion for admissibility of complaints, as it was not previously defined.

\footnotetext{
77 Hertogh [and] Oosting Marten (1996): p. 261.

${ }^{78}$ Leino (2004): "The wind is in the North. The first European Ombudsman (1995-2003)", In: European Public Law, vol.X, No. 2, p. 345.

79 The initiative of the Commission in publishing a standard form for complaints about breaches of Community law and of the Council and the Commission in adopting a Code of Conduct concerning public access to documents [OJ 1993, L 340, p. 41] pointed the way towards greater transparency and so did the European Code of Good Administrative Practice, both were considered valuable for the development of the European administration.

${ }^{80}$ Decision of the European Parliament on the regulations and general conditions governing the performance of the Ombudsman's duties; Adopted by Parliament on 9 March 1994 (OJ L 113, 4.5.1994, p. 15) and amended by its decisions of 14 March 2002 (OJ L 92, 9.4.2002, p. 13) and 18 June 2008 (OJ L 189, 17.7.2008, p. 25).

81 Cominelli (2002): An Ombudsman for the Europeans: Gradually moving towards "effective dispute resolution" between citizens and public administrations, In: The International Ombudsman Yearbook. vol. VI, p. 166
} 
"Clearly, there is maladministration if a Community institution or body fails to act in accordance with the Treaties and with the Community acts that are binding upon it, or if it fails to observe the rules and principles of law established by the Court of Justice and Court of First Instance".

For example, the European Ombudsman must take into account the requirement of Article F of the Treaty on European Union that Community institutions and bodies are to respect fundamental rights. Many other things may also amount to maladministration, including:

- Administrative irregularities

- Administrative omissions

- Abuse of power

- Negligence

- Unlawful procedures

- Unfairness

- Malfunction or incompetence

- Discrimination

- Avoidable delay

- Lack or refusal of information

This list is not intended to be exhaustive. The experience of national Ombudsmen shows that it is better not to attempt a rigid definition of what may constitute maladministration. Indeed, the open ended nature of the term is one of the things that distinguish the role of the Ombudsman from that of a judge. ${ }^{82}$

The restriction of the European Ombudsman's mandate to cases of maladministration means that every complaint concerning a political decision is considered outside the mandate. In several cases, a request to the European Ombudsman concerning a decision of the European Parliament or one of its committees was deemed unacceptable, and no further action was taken. ${ }^{83}$

From this it follows that there are limits, however, to what may count as maladministration. All complaints against decisions of a political rather than an administrative nature are regarded as inadmissible; complaints against the political work of the European Parliament or its organs; decisions of the Committee on Petitions or the exam of the merits of legislative acts of the Communities such as regulations and directives fall outside the scope of the European Ombudsman.

Even if a complaint is technically admissible, Art. 228 (1) (TFEU) provides that the EO is only to conduct inquiries "for which he finds grounds". This provision requires complaints to be excluded if they are manifestly ill founded, or if the complaint does not appear to contain sufficient grounds to form the basis for further inquiries.

82 The European Ombudsman, Annual Report, 1995, p. 9 and 1997 p. 22.

Available at: http://www.ombudsman.europa.eu/activities/annualreports.faces

83 Cominelli (2002): p. 167. 
In his Annual Report for 1997, and in response to a call for clarification by the European Parliament, the EO proposed the following definition:

"Maladministration occurs when a public body fails to act in accordance with a rule or principle which is binding upon it."

This definition was subsequently welcomed by the European Parliament. ${ }^{84}$

Although this definition may seem precise, it does not cover all the gradations of such a "common sense" concept, which are probably better explained through practical cases and exemplifications. The European Ombudsman himself settled that the significance of good or bad administration is generally established and concretised on a case-by-case basis. The matter can also be clarified by adopting a law or a code of conduct concerning good administrative behaviour, as has been done in many of the Member States ${ }^{85}$.

He knew his first task was to seek solutions to complaints from individuals and solve individual cases of maladministration. But he also interpreted his mission as making an exhaustive list of instances of 'malfunctioning' in European governance and proposing remedies. On the one hand, acting like a Court, he interpreted the cases submitted to him in a teleological way, in order to build a demanding doctrine of "good administration". 86

In this regard, the present European Ombudsman Prof. P. Nikiforos Diamandouros, notes that these principles generally allow the Ombudsman to assess issues more flexibly and in a more forward-looking fashion than Courts of law, for example, are able to. As his predecessor, the first European Ombudsman Jacob Söderman stated in his 1997 Annual Report, "The open ended nature of the term maladministration is one of the things that distinguish the role of the Ombudsman from that of a judge."

In this respect, he recalls a question posed by the former Danish Ombudsman, the late Professor Lars Nordskov Nielsen, on the occasion of the Danish Ombudsman's 40th anniversary, which remains just as topical ten years later. Professor Nielsen asked "whether the Public Administration Act should form the sole basis for the Ombudsman's assessment of whether a matter was dealt with correctly". ${ }^{87}$

\footnotetext{
${ }^{84}$ The European Ombudsman, Annual Report, 2002, p. 18.

Available at: http://www.ombudsman.europa.eu/activities/annualreports.faces

85 The European Ombudsman, Annual Report, 1997, p. 25.

Available at: http://www.ombudsman.europa.eu/activities/annualreports.faces

86 His interpretation of the notion of "administration" is very broad - by examining complaints about the way the Commission controls the application of law, the Council's practices in police co-operation or the internal workings of the European Parliament party groups, he has blurred the traditional frontiers between politics and administration.

See: Magnette (2003): Between parliamentary control and the rule of law: the political role of the Ombudsman in the European Union, Journal of European Public Policy, pp. 690 and 692.

87 "The role of the Ombudsman in future Europe and the mandates of Ombudsmen in future Europe" Speech by the European Ombudsman, Prof. P. Nikiforos Diamandouros, to the 9th Round Table meeting of European Ombudspersons and the Council of Europe Commissioner for Human Rights. Copenhagen, 31 March 2005. Available in: http://www.euro-ombudsman.eu.int/speeches/en/default.htm

The key of the whole argument was that the efforts to clarify and reinforce principles of good administration in written instruments can only be good for the citizens. For the national Ombudsmen however, they do raise the question of whether they are moving into a phase where they will content themselves with merely
} 
Throughout Europe, Ombudsmen apply different standards and criteria. The National Ombudsman of the Netherlands, for example, determines whether an administrative body has acted 'properly' in the matter under investigation. In France, le Médiateur de la République uses the standard of the Ombudsman and the quality of government 'equity'. Whereas the British Parliamentary Commissioner for Administration ${ }^{88}$ investigates any government action where a member of the public claims to have suffered injustice in consequence of maladministration. ${ }^{89}$

In the Treaty on European Union a similar competence is formulated for the EO, in regard to his competences he prefers not to describe them in strict terms, and it seems that a close and permanent relationship between the EO and national Ombudsmen is necessary because citizens do not always make a clear distinction between acts of national or European administrations.

Many of the complaints received by the European Ombudsman concern alleged wrongs caused by national administrative authorities. Furthermore, the national Ombudsmen are increasingly involved in dealing with matters that concern the implementation of Community law by national administrations. ${ }^{90}$

The upshot of all this is that working closely with his counterparts at the national, regional and local levels has been a key priority for the European Ombudsman since his first Annual Report and at present, he considers that it helps to ensure that citizens' complaints are dealt with promptly and effectively, and thus constitutes a central aspect of the Ombudsman's reactive role. This co-operation is equally vital for the European Ombudsman in his proactive mode, as it enables the monitoring of important developments in the world of ombudsmen, the exchange of information about European Union law and the sharing of best practice. ${ }^{11}$

supervising the correct implementation of already formulated legal rules of good administration, or whether they will continue to apply a broad and flexible concept of good administration capable of contributing to the continuous improvement of administrative behaviour. The European Ombudsman strongly advocated the importance of guarding the principle of good administration as a flexible basis for review as his daily practice. This approach can also applied by national Ombudsmen throughout Europe, who mostly appear to steer clear of a legalistic model of review. The European Ombudsman furthermore has been encouraged by recent decisions of the Court of First Instance of the European Court of Justice in Luxembourg, in which the Court - which itself applies a concept of sound or good administration - appeared to recognise the importance of maintaining a flexible principle of good administration as applied by Ombudsmen".

${ }^{88}$ The Parliamentary Commissioner for Administration might qualify too in the criteria of Human Rights Commissions. Certainly the United Nations recognises the "Defensores del Pueblo" in many Spanish-speaking countries as National Human Rights Institutions. But in Great Britain there has not yet been a body established with an all-embracing remit to look at every type of alleged human rights abuses rather than just particular species of abuse. The government has recently announced its intention to merge the country's anti-discrimination bodies into a single Equality Commission, something which has already happened in Northern Ireland.

See: Dickson, Brice (2003): "The Contribution of Human Rights Commissions to the Protection of Human Rights", Public Law, pp. 272-285. available at: http://www.nhri.net/default.asp?PID=82\&DID=2 [last visited: 15 June 2011]

89 Hertogh [and] Oosting Marten (1996): pp. 260-261.

${ }^{90}$ The European Ombusman, Annual Report, 1995, p. 15.

Available at: http://www.ombudsman.europa.eu/activities/annualreports.faces

${ }^{91}$ The European Ombusman, Annual Report, 2004, p. 113.

Available at: http://www.ombudsman.europa.eu/activities/annualreports.faces 
The fact of the matter is that in Europe over recent years we have seen a remarkable trend to create written instruments -whether binding or not-containing rules on good administration. ${ }^{92}$ Achieving the potential contained in the Charter requires proactive intervention to make citizens aware of the new possibilities opened for them and to encourage and assist public authorities at all levels of the Union to make the rights and aspirations of the Charter the touchstone for their actions. It particularly behoves the Ombudsman to raise awareness about the Charter as the debate on the Constitution is stepped up throughout the Union..$^{3}$

The result of these legal instruments has contributed to enhance the effectiveness of the Ombudsman's Office, to promote the rule of law, good administration and respect for human rights, and to reach out to citizens all over Europe. ${ }^{94}$

The enlargement of the Union ${ }^{95}$ was the central theme of all three priorities of the European Ombudsman, while his guiding philosophy in addressing them has been to be both "reactive" that means to respond to complainants, and "proactive", that is reaching out to the ombudsman's various constituencies through a variety of initiatives designed to maximise service to users. ${ }^{96}$

The nature of this new kind of 'agent', however, remains unclear. On the one hand, the Ombudsman is formally a parliamentary body, designed to strengthen the control of EU institutions and administrations by Members of the European Parliament (MEPs); it illustrates a classic logic of parliamentary accountability. On the other hand, the profile and role of this organ is close to that of a Court. It is addressed by individual complainants and it defines and applies 'general principles' to solve the cases submitted to it; as such, it is one of the organs designed to guarantee the respect of the rule of law. ${ }^{97}$

\footnotetext{
92 Article 41 of the Charter of Fundamental Rights of the European Union [2000/C 364/01] implied the introduction of a right to good administration in the European Union's Charter of Fundamental Rights and its inclusion as a part of the Treaty of Lisbon.

93 The European Ombusman, Annual Report, 2004, p. 19.

Available at: http://www.euro-ombudsman.eu.int/report/en/default.htm

94 However, Söderman considers that despite these positive achievements, the Charter is not yet fully respected in the EU administration. For example, his initiative to guarantee freedom of speech for officials by removing prior censorship of publications has not been followed in drafting the new Staff Regulations. It is also rather troubling that the Council's administration refuses to acknowledge that it should respect the Charter of fundamental rights, which was proclaimed by the Council presidency in December 2000, as the administration considers the Charter to be merely a "political declaration" without binding effect.

See: Speech by the European Ombudsman, Mr Jacob Söderman to the Committee on Petitions concerning the presentation to the European Parliament of his Annual Report for 2002, Brussels 24 March 2003

Available at: http://www.euro-ombudsman.eu.int/speeches/en/default.htm

95 This enlargement has been the most significant since its creation, it comprises 27 Member States and over 400 million citizens increasing not only the size of the European Union but also its complexity, that in relation to the role of the European Ombudsman, requires to coexist harmoniously among 25 legal systems and legal traditions within the legal order of the European Union.

${ }^{96}$ In the incoming years the three challenges will be to ensure that citizens' rights under EU law are respected at every level in the Union; to ensure that, in everything they do, the EU institutions and bodies conform to the highest standards of administration and to guarantee that the Ombudsman institution serves the citizen in the most efficient and effective way possible.
}

97 Magnette (2003): p. 677-678. 
Traditionally, the mission of the Ombudsman has been to settle individual disputes caused by unfair, abusive or erroneous decisions. This role is beneficial to the public. Ombudsmen can correct or redress individual problems when complaints are founded, or explain decisions, action or inaction of government when complaints are unfounded. Thus, they play a curative role by eliminating harm or providing suitable explanations as cases dictate, the same can be applicable to the European Ombudsman.

In doing so, Ombudsmen may note that some complaints come up repeatedly. Logically, this points to deeper, underlying reasons for the problem and indicates that the complaints are a symptom of something much more serious. When this happens, Ombudsmen conduct investigations into the source of the problem. The aim of this type of intervention is not only to resolve individual cases, but to prevent such cases from recurring in the future. ${ }^{98}$

\section{THE RIGHT TO COMPLAIN BEFORE THE EUROPEAN OMBUDSMAN}

Every European citizen, or every non-citizen having its residence in a Member State of the European Union, is able to make a complaint to the EO. Businesses, associations or other bodies with a registered office in the Union may also complain. Complaints may be made to the EO either directly, or through a Member of the European Parliament.

It is significant that individuals who are not EU citizens or residents, and legal entities not registered in a Member State are not entitled to complain to the European Ombudsman, even though they may be affected by the actions of the administrative bodies of the Community. However, the European Ombudsman has interpreted residency liberally and has also used the own-initiative inquiry alternative where there appeared to be maladministration but the complainant did not have standing because of lack of EU citizenship or residence. ${ }^{99}$

A complaint that is within the mandate of the EO must meet further criteria of admissibility before the EO can open an inquiry. The criteria as set out by the Statute of the Ombudsman are that:

The author and the object of the complaint must be identified (Art. 2.3)

The Ombudsman may not intervene in cases before Courts or question the soundness of a court's ruling (Art. 1.3)

The complaint must be made within two years of the date on which the facts on which it is based came to the attention of the complainant (Art. 2.4)

The complaint must have been preceded by appropriate administrative approaches to the institution or body concerned (Art. 2.4)

In the case of complaints concerning work relationships between the institutions and bodies and their officials and servants, the possibilities for submission of internal

${ }^{98}$ Jасову (1999): "The future of the Ombudsman", In: The International Ombudsman Anthology, (The Hague, Kluwer Law International) p. 27.

${ }^{99}$ C. ReIf (2004): p. 374. 
administrative requests and complaints must have been exhausted before lodging the complaint (Art. 2.8)

If the complainant so requests, his or her complaint has to be treated with confidentially. ${ }^{100}$

All complaints sent to the EO are registered and acknowledged. The letter of acknowledgement informs the complainant of the procedure for considering his or her complaint and includes the name and telephone number of the Legal Officer who is dealing with it.

The next step is to examine whether the complaint is within the mandate of the Ombudsman, then it must be admissible and there must be grounds for an inquiry. ${ }^{101}$

A complaint is therefore outside the mandate if:

- The complainant is not a person entitled to make a complaint.

- The complaint is not against a Community institution or body. ${ }^{102}$

- It is against the Court of Justice or the Court of First Instance acting in their judicial role.

- It does not concern a possible instance of maladministration. ${ }^{103}$

The principal task of the European Ombudsman is to examine alleged cases of maladministration in the actions of Community institutions or bodies, with the exception of the Court of Justice and the Court of First Instance when acting in their judicial role. These cases are generally brought to the attention of the Ombudsman through complaints from European citizens. The Ombudsman can also undertake investigations on his own initiative. A number of these complaints and investigations relate to questions of human rights, particularly freedom of expression and non-discrimination. ${ }^{104}$

It is said that the right to complain to the European Ombudsman is the second best-known right of citizenship, after the right to work in another Member State. The Flash Euro barometer ${ }^{105}$ poll in autumn 2002 showed that $87 \%$ of those questioned

\footnotetext{
100 See for example: Decision of the European Ombudsman on complaint 1442/2003/GG, the last that have been submitted currently against the Court of Justice of the European Communities, the complaint in this case was treated as confidential and the decision anonymised.

101 Heede (1997): "Enhancing the accountability of community institutions and bodies: the role of the European Ombudsman”, In: European Public Law, vol. III No 4, p. 589.

102 By way of illustration, the last Annual Report 2010 stated that national and regional Ombudsmen in Member States are competent to deal with many of the complaints that are outside the mandate of the European Ombudsman because they are not against a Community institution or body. See: The European Ombusman, Annual Report 2010.

Available at: http://www.ombudsman.europa.eu/activities/annualreports.faces

103 The European Ombusman, Annual Reports 1998 p. 16, 1999 p. 16 and 2001 p. 18.

All available at: http://www.ombudsman.europa.eu/activities/annualreports.faces

104 See: Council of the European Union, EU Annual Report on Human Rights, Brussels, 10 October 2003, [13449/03]

105 Since 1973, the European Commission has been monitoring the evolution of public opinion in the Member States, thus helping the preparation of texts, decision-making and the evaluation of its work. The Reports are published twice yearly by Eurobarometer, Available at: http://ec.europa.eu/public_opinion/index_en.htm
} 
knew of their right to complain to the European Ombudsman. The efforts to publicise the office therefore seem to have had a positive effect. ${ }^{106}$

The percentage of complains since the Institution was created serves to illustrate this positive effect, when the election of the Ombudsman took place in 1995, 53 complaints had already been registered, the first dating back to 8 April 1994. By the end of the year 1995, 298 complaints had been registered and a few months later, on 31 March 1996, the total had reached 537. From that point on, the rate at which complaints arrived continued to increase, exceeding two thousand per year in 2002.

During the early period, the flow of complaints showed a few tendencies that were maintained throughout the early years. ${ }^{107}$

Equally, the total number of complaints received in 2004 was 3 726. This represents an increase of $53 \%$ compared to 2003 . Of this $53 \%$ overall increase, $51 \%$ is accounted for by complaints from the 10 new Member States that joined the Union on 1 May 2004. The remaining 49\% represents an increase in complaints sent from the 15 old Member States and from elsewhere in the world, reflecting greater awareness of the European Ombudsman in the EU and beyond.

For the first time ever, more than half of the complaints were sent to the Ombudsman electronically, either by e-mail or using the complaint form on the Ombudsman's website. Complaints were sent directly by individual citizens in 3536 cases, while 190 complaints came from associations or companies.

In nearly $70 \%$ of cases, the Ombudsman was able to help the complainant by opening an inquiry into the case, transferring it to a competent body, or giving advice on where to turn for a prompt and effective solution to the problem. ${ }^{108}$

Their surveys and studies address major topics concerning European citizenship: enlargement, social situation, health, culture, information technology, environment, the Euro, defence, etc.

106 Speech by the European Ombudsman, Mr Jacob Söderman to the Committee on Petitions concerning the presentation to the European Parliament of his Annual Report for 2002:Brussels 24 March 2003;

Available in: http://www.euro-ombudsman.eu.int/speeches/en/default.htm

107 It follows that the main reasons for complaints could be found in the quest for more openness, involving access to documents and information, and staff matters, especially recruitment through competitions. Furthermore, complaints also dealt with infringements of human or fundamental rights, contractual disputes and various programmes of grants and subsidies. Most of the complaints came from individual citizens. Complaints from associations or enterprises accounted for less than $20 \%$ of the total.

The possibility to lodge a complaint through a Member of the European Parliament was rarely used. The number of complaints sent electronically, by e-mail or via the on-line complaint form on the website, went up year after year to become the majority of complaints.

Söderman (2005): “The Early Years of the European Ombudsman”, In: The European Ombudsman, Origins, Establishment and Evolution, [on line] (Luxembourg: Office for Official Publications of the European Communities) Available at: http://www.euroombudsman.eu.int/10anniversary/en/default.htm; ISBN 92 95022-85-8

108 In general and according to the last statistics available since 2004 (375 cases accounting for $69 \%$ of all inquiries opened). has shown that most of the complaints that led to an inquiry are against the European Commission, in 2010 were 219 cases concerned the European Commission (65\%).

As the Commission is the main Community institution that makes decisions having a direct impact on citizens, it is normal that it should be the principal object of citizens' complaints. See: The European Ombudsman, Annual Report, 2010; p. 27 available in: http://www.ombudsman.europa.eu/activities/ annualreports.faces 
As is the case each year, most inquiries opened by the Ombudsman in 2010 concerned the Commission (219 inquiries or $65 \%$ of the total). Since the Commission is the main EU institution that makes decisions having a direct impact on citizens, it is logical that it should be the principal object of citizens' complaints.

It should be noted, however, that the comparable figure for 2009 was $56 \%$ of the total. There were 35 inquiries (10\%) concerning the European Personnel Selection Office (EPSO), 22 (7\%) concerning the European Parliament, 6 (2\%) concerning the Council of the EU, and $4(1 \%)$ concerning the Court of Justice of the European Union. With regard to the Court, it is important to mention that the Ombudsman can only open inquiries into its non-judicial work. The main types of alleged maladministration investigated by the Ombudsman in 2010 were (i) breaches of: lawfulness (incorrect application of substantive and/or procedural rules (20.6\% of inquiries), reasonable time limits for taking decisions (14.1\%), fairness (11\%), the duty to state the grounds of decisions and the possibilities of appeal (5.8\%), the obligation to reply to letters in the language of citizens, indicating the competent official (5.5\%), and the duty of care (3.1\%); (ii) breaches of duties relating to: requests for information (30.4\% of inquiries), requests for public access to documents (6.7\%), and ensuring the absence of discrimination (3.7\%). In over $70 \%$ of cases processed, we were able to help the complainant by opening an inquiry into the case, transferring it to a competent body, or giving advice on where to turn. ${ }^{109}$

Actually, the right to complain to the Ombudsman appears in Part II about Nondiscrimination and citizenship of the Union, Article 20 (TFEU) as well as in Article 44 of the Charter of Fundamental Rights of the EU and the the right to refer to the European Ombudsman cases of maladministration in Article 43 of the Charter.

\section{CONCLUSION}

What should be established is that the European Ombudsman has a dual role. On the one hand, the institution provides a cheap, flexible and accessible form of redress for individual grievances. In this respect, the Ombudsman reinforces the rule of law in the Community and complements the role of the Courts. On the other hand, the Ombudsman helps make the European Union more accountable to all its citizens by providing an independent critical appraisal of the quality of administration by Community institutions and bodies and a stimulus towards improvement. As an independent agency for promoting accountability, the Ombudsman complements the representative role of the European Parliament. ${ }^{110}$

In addition when investigating complaints, the Ombudsman considers himself a controller of Community supervising on administrative procedures in which the liberties and rights of the EU citizens should be protected. By responding instances of "maladministration" and by trying to guarantee that certain general principles of

\footnotetext{
109 The European Ombudsman, Annual Report, 2010, p. 28.

Available at: http://www.ombudsman.europa.eu/activities/annualreports.faces

110 Heede (1997): p. 588.
} 
procedure are followed for all European citizens, the EO has developed the right to "good administration" under the scope of the EU even before it was officially codified. Also the duties of the EO are prescribed by EC/EU law and executed through formal proceedings.

Simultaneously, the European Ombudsman has also been developing preventative measures against maladministration that widen further than the official scope of his mandate. These warnings, opinions and proposals are intended to adapt EU structures and institutions to the standards of a supranational community to the rule of law. The simple fact that someone is watching over these bodies urges them to act properly.

Another factor to take into account is his duty to promote good administration, for more than a decade the EO has elaborated general principles, rules of conduct, and criteria of good administration. These criteria have been published in various forms, including reports, speeches, letters, notes and press releases. But an even more important factor was the promotion of good administration in the Code of Good Administrative Behaviour -that includes general principles of procedure common to all Community institutions - this Code approved by the Parliament in 2001 and published in its latest version in 2005 , represents a preliminary attempt to codify general rules on Community administrative procedure and has been elaborated to encourage all Community institutions to adopt it ever since, although the Code still remains part of soft law.

In the final analysis we can conclude that the European Ombudsman has taken progressively the role as controller of maladministration and codifier, becoming closer to the citizens than the other EU institutions.

Throughout his Annual and Special Reports he can also share information and encourage cooperation not only between Community institutions and their counterparts at the national level but also with national Ombudsmen and national Courts, improving public access to justice, access to information and prevention of conflicts.

Here, the EO could play a pivotal role by condemning cases of maladministration that may constitute a violation of fundamental rights and are symptomatic of recurring malfunctions in European bureaucracy. Individuals will always find a need for additional protection against administrative arbitrariness not only at the level of a contemporary State but also at a supranational level.

In this regard we must point out that the EO is entitled to apply principles and procedural rules on good administration and transparency enshrined in Articles 41 and 42 of the Charter of Fundamental Rights. With this in view, the European Ombudsman could enjoy fruitful cooperation with the future Fundamental Rights Agency and play an important role in the multi-layered structure ("network of networks") so as to avoid overlapping of activities by different bodies. ${ }^{11}$

This is especially important when there is a need of opening up the EU institutions to greater public scrutiny in which the European Ombudsman is playing a key role to legitimate the institutionalism of the EU, contributing to its institutional balance and to reduce the EU's democratic deficit, becoming a tool for citizen's participation.

111 European Parliament, Report on the annual report on the activities of the European Ombudsman for the year 2004, Committee on Petitions session document 2005-2009 [2005/2136(INI)] 
His position is highly unique with regard to EU system, although appointed by the EP he is independent from this institution, and the same applies to his relationship with the Council and the Commission, to which he does not belong and whose activities he investigates. At last, the European Ombudsman is also independent from the EU Courts, but he may perhaps receive complaints about the maladministration of court officials, because of negligence, unnecessary delays, etc. matters which are not under the extent of their judicial role.

In conclusion, it remains to be seen whether the European Ombudsman now will be willing to go beyond its scope of functions, shaping and forming a European publicity, by being an institution which is tangible and reachable by the citizens and therefore giving them an opportunity to address their needs, turning to them in order to exercise their fundamental rights and defend their interests.

Finally, let us remember that these rights have influenced centrally in nearly all of the matters dealt with by the European Ombudsman, who in many of his decisions and reports has emphasised the importance of interpreting EU law in a way that favours fundamental rights. The emphasis in oversight of legality has changed more and more towards providing EU's authorities with advice and guidance. Above all fundamental rights are intended to guarantee institutionalized governance at the EU level, together with legal security and practices of good administration.

\section{BIBLIOGRAPHY}

\section{Books}

Alston, Philip (1999): The EU and Human Rights (Great Britain, Oxford University Press) $976 \mathrm{pp}$.

C. ReIf, Linda (2004): The Ombudsman, Good Governance and the Internacional Human Rights System (Leiden, Martinus Nijhoff Publishers) 432 pp.

Craig, Paul [and], De. Búrca, Gráinne (1998): EU Law. Text, cases and materials (USA, Oxford University Press, 2nd Ed.) 1138 pp.

Craig, Paul [and], De. Búrca, Gráinne. (2003): EU Law. Text, cases and materials. (Oxford, Oxford University Press) 1241 pp.

Crespo Allen, Marília (2001): European Ombudsman and National Ombudsmen or similar bodies comparative tables (Luxembourg, European Parliament) 102 pp.

Habermas, Jürgen (1998): Between Facts and Norms, Contributions to a Discourse Theory of Law and Democracy (translated by Wiliam Rehg, Cambridge, Massachusetts, 1st Edition) 595 pp.

Micklitz, Hans-Wolfgang (2005): The politics of judicial co-operation in the EU: Sunday trading, equal treatment and good faith (Cambridge, Cambridge Univ. Press) 539 pp.

Rowat, Donald C. (1973) El Ombudsman: el Defensor del Ciudadano (México, Fondo de Cultura Económica) 462 pp.

\section{Articles}

BizJAK, Iván (1998): "The role and experience of an Ombudsman in a new democracy", In: The International Ombudsman Yearbook, No. 2, pp. 57-62. 
Cominelli, Luigi (2002): "An Ombudsman for the Europeans: Gradually moving towards "effective dispute resolution" between citizens and public administrations", In: The International Ombudsman Yearbook. vol. VI, pp. 143-182.

Gjerloeff Bonnor, Peter (2000): “The European Ombudsman: a novel source of soft law in the European Union”, In: European Law Review, vol. XXV: pp. 39-56.

Harden, Ian. (2000): "When Europeans complain. The work of the European Ombudsman”, In: The Cambridge Yearbook of European Legal Studies, vol.III (OxfordPortland Oregon) pp. 199-237.

Harlow, Carol (1999) "Access to Justice as a Human Right: The European Convention and the European Union", In: Alston, Philip. The EU and Human Rights (Great Britain, Oxford University Press) pp. 187-214.

Heede, Katja (1997): "Enhancing the accountability of community institutions and bodies: the role of the European Ombudsman”, In: European Public Law, vol. III No4: pp. 587-605.

JaCoвy, Daniel (1999): “The future of the Ombudsman”, In: C. Reif, Linda (ed.), The International Ombudsman Anthology (The Hague, Kluwer Law International) pp. 1543.

Kempf, Udo (1996): “Ombudsmanship without an Ombudsman: Germany" In: The European yearbook of comparative government and public administration, vol. III: pp. 321-336.

Leino, Päivi (2004): "The wind is in the North. The first European Ombudsman (19952003)”, In: European Public Law, Vol.X No2, pp. 333-367.

Magnette, Paul (2003): "Between parliamentary control and the rule of law: the political role of the Ombudsman in the European Union”, In: Journal of European Public Policy, vol. X No5: pp. 677-694.

Matteis, Antonio de (2003): "Il Mediatore Europeo", In: Rivista Italiana di Diritto Pubblico Comunitario, vol. XIII No5: pp. 1191-1203.

Peters, Anne (2005): “The European Ombudsman and the European Constitution”, In: Common Market Law Review (Netherlands, Kluwer Law International) No.42, pp. 697-743.

SNyder, Francis, (1994): "Soft Law and Institutional Practice in the European Community", In The Construction of Europe: Essays in Honour of Emile NOEL (ed. Stephen D. Martin, Kluwer, Deventer), pp. 197-225

Söderman, Jacob (1997): "A thousand and one complaints: The European Ombudsman en route", In: European Public Law, vol. III, No. 4, pp. 351-361

\section{Online Sources}

Dickson, Brice (2003): "The Contribution of Human Rights Commissions to the Protection of Human Rights", Public Law, pp. 272-285. available at: http://www.nhri.net/default. asp?PID=82\&DID=2 [last visited: 15 June 2011]

Eeckhout, Jean-Claude [and] Godts, Philippe (2005): The European Commission's Internal Procedure for Dealing with the European Ombudsman's Inquiries, In: The European Ombudsman, Origins, Establishment and Evolution, [on line] Luxembourg: 
Office for Official Publications of the European Communities, p. 167 Available at: http://www.euroombudsman.eu.int/10anniversary/en/default.htm

Eiselt, Isabella [and] Stominski, Peter (2004): The Negotiation of the Interinstitutional Declaration on Democracy, Transparency and Subsidiarity, (Austria, Working Paper Nr: 4, (EIF) Institute for European Integration Research) available at: http://www.eif. oeaw.ac.at/downloads/projekte/wp4.pdf Eurobarometer Surveys, Available at: http:// ec.europa.eu/public_opinion/index_en.htm

Human rights and non-judicial remedies - The European Ombudsman's perspective"; Speech by the European Ombudsman, Professor P. Nikiforos Diamandouros, at the London School of Economics and Political Science, London, 30 November 2005 Available at: http://www2.1se.ac.uk/humanRights/events/European_Ombudsman.aspx

Speech by the European Ombudsman, Mr Jacob Söderman to the Committee on Petitions concerning the presentation to the European Parliament of his Annual Report for 2002: Brussels 24 March 2003 Available in: http://www.euro-ombudsman.eu.int/ speeches/en/default.htm

The European Code of Good Administrative Behaviour. Available at: http://www. ombudsman.europa.eu/resources/code.faces

The European Ombudsman - Origins, Establishment and Evolution, (2005): (Luxembourg, Office for Official Publications of the European Communities), ISBN 92-95022-858 Available at: http://www.ombudsman.europa.eu/en/resources/historicaldocument. faces/en/10122/html.bookmark [last visited: 14 June 2011].

The European Ombusman (1995-2011), Annual Reports, Available at: http://www. ombudsman.europa.eu/activities/annualreports.faces

The European Ombusman (2010), Oveview 2010, Available at: http://www.ombudsman. europa.eu/activities/annualreports.faces

"The role of the Ombudsman in future Europe and the mandates of Ombudsmen in future Europe"; Speech by the European Ombudsman, Prof. P. Nikiforos Diamandouros, to the 9th Round Table meeting of European Ombudspersons and the Council of Europe Commissioner for Human Rights, Copenhagen, 31 March 2005 Available in: http:// www.euro-ombudsman.eu.int/speeches/en/default.htm

\section{Quoted Norms}

Basic Law for the Federal Republic of Germany 23 May 1949 (Federal Law Gazette, p. 1) (BGBl III 100-1) most recently amended by "Basic Law for the Federal Republic of Germany in the revised version published in the Federal Law Gazette Part III, classification number 100-1, as last amended by the Act of 29 July 2009 (Federal Law Gazette I p. 2248)

Consolidated Version of the Treaty on the Functioning of the European Union (TFEU). Official Journal, 9 May 2008 [C 115/47)]

Constitution of the Italian Republic, 27 December 1947 Publications Office of the Senate Service for Official Reports and Communication.

Danish proposal for a European Ombudsman. Danish proposal to the Intergovernmental Conference on Political Union, 21 February 1991. 
Decision of the European Parliament on the regulations and general conditions governing the performance of the Ombudsman's duties, adopted by the Parliament on 9 March 1994 Official Journal, [OJ L 113, 4.5.1994] and amended by its decision of 14 March 2002 deleting Articles 12 and 16 Official Journal, [OJ L 92, 9.4.2002] and Council Decision of 7 February 1994 approving the Decision of the European Parliament on the regulations and general conditions governing the performance of the Ombudsman's duties (94/114/ECSC, EC, EURATOM).

Draft recommendation of the European Ombudsman in the own initiative inquiry, 13 September 1999 [OI/1/98/OV].

European Parliament Decision 2008/587 of 18 June 2008, amending Decision 94/262 on the regulations and general conditions governing the performance of the Ombudsman's duties, Official Journal, 18 June 2008 [OJ 2008 L 189].

European Union (2010): Consolidated Treaties and Charter of Fundamental Rights, (Luxemburg, Publications Office of the European Union).

Interinstitutional Agreement on the budgetary procedure of 29 October 1993. Official Journal, 7 December 1993 [OJ C 331]

Laeken Declaration of 15 December 2001 on the future of the European Union, Official Journal, 18 December 2000 [OJ C 364].

Official position of the European Parliament, Texts adopted: Resolution on the outcome of the Copenhagen European Council meeting of 21-22 June 1993 [B3-0947/93].

Recommendation of the European Commission on Turkey's progress towards accession. Communication from the Commission to the Council and the European Parliament, 6 October 2004. [06.10.2004; COM (2004) 656].

Regulation (EC) No 1049/2001 of the European Parliament and of the Council regarding public access to European Parliament, Council and Commission documents, Official Journal, 30 May 2001. [OJ 2001 L 145].

Resolution on the appointment of a Community Ombudsman by the European Parliament. Official Journal, 11 May 1979.

Schengen Agreement of 14 June 1985 and on the gradual abolition of checks at common borders and Convention determining the State responsible for examining applications for asylum lodged in one of the Member States of the European Communities Dublin Convention, 19 August 1997 [OJ C 254].

The "Adonnino Report" Report to the European Council by the ad hoc committee "On a People's Europe”,Milan, 28 and 29 June 1985 [A 10.04 COM 85, SN/2536/3/85.].

The Constitutional Treaty of 29 October 2004 Official Journal of the European Union 16 December 2004.

Treaty of Lisbon amending the Treaty on European Union and the Treaty establishing the European Community. European Union, Consolidated Treaties and Charter of Fundamental Rights (Luxemburg, Publications Office of the European Union) 13 December 2007.

Treaty establishing the European Community (Rome, 25.3.1957, lastly amended by the Accession Treaty 2003) Consolidated version 1 November 2004. 
